\title{
PENGORGANISASIAN DALAM MANAJEMEN
}

\author{
Saefrudin 1 \\ e-mail: saefrudintbi@gmail.com
}

\begin{abstract}
Humans are organizational beings. Therefore, once he was born into the world, he became a member of a genetic organization called members of a family organization. When school age, man enters school and he becomes a member of the school. After graduation and work, he became a member of the organization at his workplace. He may also be a member of a religious, youth, political, economic, and so on. Finally, after the human died he was recorded as a member of the organization of death by the death association committee at RT level.

Thus, human beings from birth to death cannot be separated from the organization. Humans are organizational beings because from birth humans cannot live alone without the help of others. Organizations are formed for the benefit of humans (anthropocentric), organizations are actually created for people, not for organizations. Therefore, every day people are in touch with their organizations. Although the experience of organizing that there is a fun and annoying, there are positive and some are negative, but people still need the organization. The existence of this contradiction as a consequence that man is essentially not the same or full of differences.

This difference occurs because of different educational background, experience, socioeconomic status, culture, age and so on. Not a single human being is identical, even if they are twins. Humans differ mainly from their fingerprints. What equates them is that they remain the same as humans
\end{abstract}

Keywords: Organization, Management

\section{Pendahuluan}

Dalam dunia pendidikan terdapat manajemen yang berfungsi untuk megatur jalannya pendidikan tersebut. Di mana manajemen itu mempunyai beberapa fungsi yaitu perencanaan, pengorganisasian, penggerakan dan pengendalian. Maka dari itu dalam makalah akan mengulas sedikit tentang pengorganisasian, yang mana perencanaan dalam manajemen tidak akan berjalan atau berhasil tanpa adanya pengorganisasian dan pengorganisasian tidak akan pernah ada tanpa adanya manusia.

\footnotetext{
${ }^{1}$ Dosen Tetap Fakultas Tarbiyah Sekolah Tinggi Ilmu Syari’ah Faqih Asy’ari
} 
Manusia, dalam perjalanan hidup dan kehidupannya, pada dasarnya mengemban amanah atau tugas-tugas kewajiban dan tanggung jawab yang dibebankan Allah kepada manusia agar dipenuhi, dijaga dan dipelihara dengan sebaikbaiknya. ${ }^{2}$ Manusia juga merupakan makhluk multidimensioal. Oleh karena itu, banyak julukan-julukan yang diberikan kepadanya, misalnya manusia sebagai makhluk sosial, berpikir, yang suka menggunakan lambang-lambang, organisasional dan lain-lain.

Manusia adalah makhluk organisasi. Oleh karena itu, begitu ia dilahirkan ke dunia, ia menjadi anggota organisasi genitis yang disebut anggota organisasi keluarga. Ketika usia sekolah, manusia memasuki sekolah dan ia menjadi anggota sekolah. Setelah lulus dan bekerja, ia menjadi anggota organisasi di tempat kerjanya. Mungkin pula ia merangkap menjadi anggota organisasi agama, pemuda, politik, ekonomi dan sebagainya. Akhirnya, setelah manusia meninggal ia dicatat sebagai anggota organisasi kematian oleh panitia rukun kematian di tingkat RT.

Jadi, manusia sejak dilahirkan sampai kematiannya tidak dapat dipisahkan dari organisasi. Manusia adalah makhluk organisasional karena sejak lahir manusia tidak dapat hidup sendiri tanpa bantuan orang lain. Organisasi dibentuk untuk kepentingan manusia (antroposentris), organisasi sebenarnya diciptakan untuk orang, bukan untuk organisasi. Oleh karena itu, setiap hari manusia berhubungan dengan organisasinya. Walaupun pengalaman berorganisasi itu ada yang menyenangkan dan menjengkelkan, ada yang positif dan ada pula yang negatif, tetapi manusia tetap saja memerlukan organisasi. Adanya pertentangan ini sebagai konsekuensi bahwa manusia pada hakikatnya tidak sama atau penuh dengan perbedaan. ${ }^{3}$

Perbedaan ini terjadi antara lain karena latar belakang pendidikan, pengalaman, status sosial ekonomi, budaya, usia dan sebagainya yang berbeda. Tidak ada satu pun manusia yang sama persis, sekalipun mereka kembar. Manusia berbeda terutama dari sidik jarinya. Yang menyamakan mereka ialah mereka tetap sama-sama bernama manusia Untuk memahami pengorganisasian dalam manajemen ini, maka pada uraian selanjutnya akan dibahas tentang: Apa yang dimaksud dengan pengorganisasian, apa saja faktor-faktor yang menentukan struktur organisasi, Bagaimana bentuk-bentuk organisasi, apa saja yang mempengaruhi lingkungan organisasi dan globalisasi, bagaimana dinamika organisasi, Manusia perlu berorganisasi dengan tujuan dan

\footnotetext{
${ }^{2}$ Muhaimin, dkk, Paradigma Pendidikan Islam (Upaya Mengefektifkan Pendidikan Agama Islam di Sekolah), (Bandung: PT Remaja Rosdakarya, 2012), h. 19.

${ }^{3}$ Husaini Usman, Manajemen (Teori, Praktik, dan Riset Pendidikan), (Jakarta: Bumi Aksara, 2009), h. 146 .
} 
manfaat, antara lain untuk 1) mencapai tujuan secara lebih efektif dan efisien karena dikerjakan bersama-sama (motif pencapaian tujuan); 2) wadah untuk memanfaatkan sumber daya dan teknologi bersama-sama; 3) wadah mengembangkan potensi dan spesialisasi yang dimiliki seseorang (motif berprestasi); 4) wadah mendapatkan jabatan dan pembagian kerja; 5) wadah mengelola lingkungan secara bersama-sama; 6) wadah mencari keuntungan bersama-sama (motif uang); 7) wadah menggunakan kekuasaan dan pengawasan (motif kekuasaan); 8) wadah memenuhi kebutuhan manusia yang semakin banyak dan kompleks.

\section{Pembahasan}

Pengorganisasian adalah proses membagi kerja ke dalam tugas-tugas yang lebih kecil, membebankan tugas-tugas itu kepada orang yang sesuai dengan kemampuannya, dan mengalokasikan sumber daya, serta mengkoordinasikannya dalam rangka efektivitas pencapaian tujuan organisasi. Hal tersebut dapat dituangkan dalam bagan proses pengorganisasian sebagai berikut:

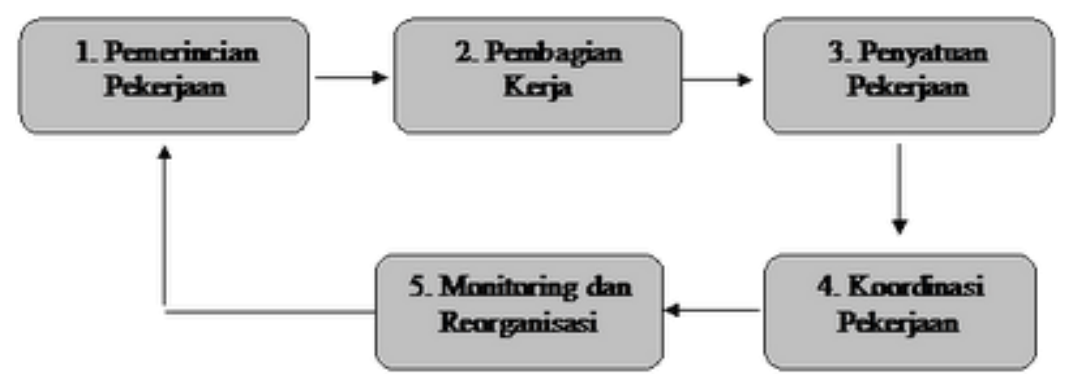

Gambar 4: Proses Pengorganisasian

Dengan demikian diketahui bahwa unsur-unsur dasar pembentuk organisasi ada beberapa yaitu pertama, Adanya tujuan bersama, kedua adanya dua orang atau lebih, ketiga adanya pembagian kerja yang jelas, keempat adanya kerja sama yang baik.

Pada struktur organisasi tergambar posisi kerja, pembagian kerja, jenis kerja yang harus dilakukan, hubungan atasan dan bawahan, kelompok, komponen atau bagian, tingkat manajemen dan saluran komunikasi. Suatu struktur organisasi memberikan spesifikasi pembagian kegiatan kerja dan menunjukkan bagaimana fungsi atau kegiatan kerja dan menunjukkan bagaimana fungsi atau kegiatan yang berbeda-beda itu dihubungkan. Struktur juga menunjukkan hierarki dan struktur wewenang organisasi serta memperlihatkan hubungan pelapornya. 
Menurut Stoner struktur organisasi dibangun oleh lima unsur, yaitu: ${ }^{4}$

a. Spesialisasi aktivitas, yaitu mengacu pada spesifikasi tugas perorangan dan kelompok di seluruh organisasi atau pembagian kerja dan penyatuan tugas tersebut ke dalam unit kerja (departementalisasi).

b. Standardisasi aktivitas, yaitu merupakan prosedur yang digunakan organisasi untuk menjamin kelayak-gunaan (predictability) aktivitas banyak dari prosedur ini ditetapkan dengan memformulasikan aktivitas dan hubungan dalam organisasi.

c. Koordinasi aktivitas, adalah prosedur yang memadukan fungsifungsi dalam organisasi, seperti fungsi primer dalam suatu badan usaha, pemasaran, produksi dan penjualan merupakan fungsi garis yang secara langsung menyumbangkan pada pencapaian tujuan organisasi memerlukan koordinasi.

d. Sentralisasi dan desentralisasi pengambilan keputusan, mengacu pada lokasi kekuasaan pengambilan keputusan. Sentralisasi ialah proses konsentrasi wewenang dan pengambilan keputusan pada tingkat atas suatu organisasi. Sedangkan desentralisasi adalah pendelegasian wewenang pada semua tingkat organisasi.

e. Ukuran unit kerja, mengacu pada jumlah pegawai dalam suatu kelompok kerja.

Dengan demikian dapat disimpulkan bahwa pengorganisasian menyangkut penentuan pekerjaan, pembagian kerja, penetapan mekanisme untuk mengkoordinasikan kegiatan, salah satu hasil proses ini adalah struktur organisasi yang merupakan prosedur formal manajemen organisasi. Struktur ini dibentuk sangat bergantung pada tujuan organisasi dan strategi yang akan dipergunakan untuk mencapai tujuan itu.

Karakteristik struktur organisasi ini menurut teori birokrasi antara lain:

a. Menekankan pada bentuk,

b. Konsep hierarki,

c. Spesialisasi tugas,

d. Kegiatan khusus,

e. Mendukung norma, dan

f. $\operatorname{catatan}^{5}$

\footnotetext{
${ }^{4}$ Stoner, Management, alih bahasa Wihelmus W. Bakowatun (Jakarta: Intermedia, 1986).

${ }^{5}$ Husaini, Manajemen, h. 169.
} 
Sedangkan struktur organisasi menurut Jones, antara lain: 1) sistem formal yang mengontrol pemanfaatan SDM, koordinasi, motivasi, perilaku, dan organisasi; 2) respons terhadap lingkungan, teknologi, dan SDM; 3) pertumbuhan organisasi dan diferensiasi; dan 4) pengatur perubahan melalui desain organisasi. ${ }^{6}$

Adapun langkah-langkah dalam mendesain struktur organisasi, sebagai berikut: $^{7}$

a. Bagan tanggung jawab, bagan organisasi, dan prosedur standar hendaknya ditulis dan diperinci serinci mungkin dengan mengingat tujuan umum, kemungkinan adanya reorganisasi di kemudian hari, dan menjamin kelangsungan karier personalianya.

b. Apabila organisasi berkembang dan perlu penambahan tanggung jawab untuk personalianya, hendaknya didasarkan pada fungsi atau spesialisasi dari operasi.

c. Pucuk pimpinan diberikan tanggung jawab untuk menetapkan kebijakan yang menyangkut keseluruhan kegiatan organisasi.

d. Jika penetapan kebijakan ini di desentralisasikan, hendaknya dijelaskan batas-batasnya.

e. Garis pertanggungjawaban hendaknya dirumuskan dengan jelas, sehingga terpisah dengan garis komando.

f. Struktur hendaknya cukup luwes guna memberi kesempatan perubahan jika dikehendaki, namun agar menjamin kesuksesan organisasi, perlu ditetapkan garis-garis besar dan kode-kode yang fundamental. Hal ini untuk menjamin daya guna organisasi, walaupun ada reorganisasi.

g. Tidak ada tipe organisasi tertentu yang dapat diterapkan untuk semua kepentingan, khususnya sejak dipertimbangkannya karakteristik individu, yaitu sejak personalia ditempatkan sebagai pusat kekuatan sedemikian rupa sehingga mampu memanfaatkan segala kekuatan personalianya, dan terhindar dari pengaruh yang merupakan kelemahan personalianya.

Dalam praktiknya, proses organisasi merupakan kompromi antara kesempurnaan, alasan logis dan kebenaran.

${ }^{6}$ G.R. Jones, Organizational Theory Text and Cases (New York: Addison Wesley Publishing Company, 1995).

7 Heidjrachman Ranupandojo, Teori dan Konsep Manajemen (Yogyakarta: AMP YKPN, 1996), h. 61. 
Bentuk-bentuk organisasi dapat berupa: organisasi garis, organisasi garis dan staf, organisasi fungsional, organisasi matrik, dan organisasi proyek. ${ }^{8}$

a. Organisasi garis

Organisasi garis merupakan bentuk tertua organisasi dan paling sederhana. Biasanya terdapat dalam organisasi yang relatif kecil. Struktur ini tidak cocok digunakan dalam organisasi yang besar karena kompleks dan luasnya bidang garapan yang harus ditangani organisasi sehingga memerlukan adanya pendelegasian wewenang kepada bawahannya.

Dalam struktur organisasi garis anggotanya relatif sedikit dan sebagai pimpinan puncak organisasi biasanya adalah pemiliknya atau pemegang saham yang paling besar. Struktur organisasi garis disebut juga struktur organisasi militer. Ciri-cirinya adalah satu orang bawahan hanya memiliki seorang atasan, jadi dia hanya menerima perintah kerja dari satu orang saja, yaitu pimpinannya.

Kelebihannya adalah: 1) Proses pengambilan keputusan dapat berjalan dengan cepat karena jumlah yang perlu diajak berkonsultasi masih sedikit; 2) Rasa solidaritas para anggota pada umumnya masih besar dan masih saling kenal; 3) Rasa disiplinnya masih tinggi.

Adapun kekurangannya adalah: 1) Tujuan organisasi sama, satu paling sedikit didasarkan atas tujuan pribadi pimpinan tertinggi dalam organisasi; 2) Kecenderungan bagi pimpinan organisasi untuk bertindak diktatoris/otokratis cukup besar karena dipandang sebagai milik pribadi dan oleh karenanya kemauannya yang secara tepat harus dituruti; 3) Seluruh organisasi terlalu bergantung pada seseorang sehingga kalau seseorang itu tidak mampu melaksanakan tugasnya, maka seluruh organisasi itu terancam oleh ketidak langsungan kehidupannya; 4) Kesempatan bagi para karyawan untuk mengembangkan spesialisasi sangat terbatas. ${ }^{9}$

b. Organisasi garis dan staf

Organisasi ini terdiri atas dua kelompok orang-orang yang berpengaruh dalam menjalankan roda organisasi. Kelompok pertama menjalankan tugas-tugas pokok organisasi untuk mencapai tujuan, yang ditempatkan dalam kotak-kotak garis (line), sedangkan kelompok yang kedua, melakukan tugas-tugas berdasarkan keahliannya yang disebut staf. Staf dapat memberikan saran-

\footnotetext{
8 Ibid., h. 63.

${ }^{9}$ http://belajarmanagement.wordpress.com/2010/02/24/bentuk-bentuk-organisasi/.
} 
sarannya kepada unit operasional. Staf juga memberikan pengaruh dalam pelaksanaan. ${ }^{10}$

Ciri-cirinya sama dengan organisasi garis hanya ditambah adanya staf yang berfungsi memberikan nasehat atau pertimbangan-pertimbangan kepada pimpinan.

Kelebihannya adalah: 1) Ada pembagian tugas yang jelas antara orangorang yang melaksanakan tugas-tugas pokok dan tugas-tugas penunjang; 2) Bakat yang berbeda-beda dari pada para anggota organisasi dapat dikembangkan menjadi suatu spesialisasi; 3) Koordinasi mudah dijalankan dalam setiap kelompok dari kedua golongan karyawan itu; 4) Disiplin serta moral biasanya tinggi karena tugas yang dilaksanakan oleh seorang sesuai dengan bakat keahlian, pendidikan dan pengalamannya; 5) Bentuk organisasi ini dapat dipergunakan oleh setiap organisasi yang bagaimanapun besarnya, apa pun tujuannya dan betapa pun kompleksnya struktur organisasi.

Adapun kekurangannya adalah: 1) Bagi para pelaksana tingkat operasional tidak selalu jelas yang mana perintah, yang mana nasehat. Artinya orang-orang lini dihadapkan pada dua macam atasan. Pertama, atasan yang telah ditentukan dalam garis komando, yang mempunyai hak memerintah. Kedua, para pelaksana operasional itu dihadapkan pula kepada pimpinan staf, yang meskipun hanya berhak memberikan nasehat, yang perlu pula ditaati karena nasehat itu didasarkan kepada keahlian dan wewenang fungsional; dan 2) Perintah dari hierarkhi lini tidak selalu seirama dengan nasehat dari hierarkhi staf, karena belum tentu kedua macam hierarkhi memandang suatu hal dari kaca mata yang sama. ${ }^{11}$

c. Organisasi fungsional

Organisasi fungsional adalah organisasi yang pembagian tugas atas para pejabatnya disesuaikan dengan bidang keahliannya. Organisasi ini tidak terlalu menekankan pada hierarki struktural, namun lebih menekankan pada sifat dan macam fungsi yang akan dilaksanakan. ${ }^{12}$ Cirinya adalah seorang bawahan dapat menerima perintah dari banyak atasan. Contohnya organisasi bengkel. Seorang tukang las, dapat menerima perintah dari banyak departemen yang memerlukan jasa mengelas.

Kelebihannya adalah: 1) Spesialisasi para karyawannya dipergunakan semaksimal mungkin; 2) Solidaritas antara orang-orang yang menjalankan fungsi

\footnotetext{
${ }^{10}$ Husaini, Manajemen, h. 170.

${ }^{11} \mathrm{http}: / /$ ulfahfauziyah.blogspot.com/2012/10/bentuk-bentuk-organisasi.html.

${ }_{12}$ Husaini Usman, Manajemen, h. 171.
} 
yang sama pada umumnya tinggi; 3) Moral serta disiplin orang-orang yang menjalankan fungsi yang sama pada umumnya tinggi; dan 4) Koordinasi antara orang-orang dalam satu fungsi mudah dijalankan.

Kekurangannya: 1) Orang menspesialisasikan diri dalam satu bidang kegiatan tertentu sehingga sukar untuk mengadakan tour of duty dan tour of area tanpa melalui pendidikan yang intensif lebih dahulu dan 2) Orang-orang yang bergerak dalam satu bidang fungsi tertentu terlalu mementingkan fungsinya saja sehingga koordinasi yang bersifat menyeluruh sukar untuk dijalankan.

Bentuk organisasi Fungsional adalah bentuk di mana pimpinan dan para pelaksana dibentuk dalam kelompok-kelompok yang bersifat panitia. Artinya pada tingkatan pimpinan, keseluruhan unsur pimpinan menjadi panitia dan para pelaksana dibagi-bagi dalam kelompok-kelompok yang bersifat task force. ${ }^{13}$

d. Organisasi matrik

Organisasi matriks merupakan penyempurnaan dari organisasi fungsional. Orang-orang yang ditugaskan dalam setiap sel tidak hanya termasuk dalam organisasi fungsional, tetapi juga dalam organisasi produk.

Cirinya adalah dalam organisasi itu terjadi kontak koordinasi antar bagian yang ada dalam organisasi. Organisasi matriks menggunakan pendekatan struktural dan fungsional sekaligus (kombinasi).

Kelebihannya di antaranya: 1) efisiensi penggunaan manajer-manajer fungsional; 2) luwes menghadapi perubahan dan ketidakpastian; 3) keunggulan teknis; 4) meningkatkan motivasi kerja; 5) pengembangan diri.

Kekurangannya: 1) terjadinya konflik karena adanya pertanggungjawaban ganda yang dapat menimbulkan kebingungan dan kebijakan-kebijakan yang kontradiktif serta pertentangan kekuasaan yang mengarah pada perdebatan atas suatu kegiatan; 2) memerlukan koordinasi vertikal dan horizontal; 3) memerlukan lebih banyak keterampilan antarpribadi; 4) sangat mahal diterapkan; 5) mengandung risiko timbulnya anarki.

e. Organisasi proyek

Cirinya adalah apabila tujuan proyek sudah selesai, maka organisasi ini akan segera dibubarkan. Jadi sifat organisasinya hanya sementara saja, yaitu selama proyeknya berjalan.

Dalam sudut formalitas, ada dua bentuk organisasi, yaitu organisasi formal dan organisasi informal. ${ }^{14}$

\footnotetext{
${ }^{13} \mathrm{http}: / /$ dedetzelth.blogspot.com/2013/03/bentuk-bentuk-organisasi 17.html.

${ }_{14}$ Ranupandojo, Tanya Jawab., h. 64.
} 
1. Dalam organisasi formal terdapat pembagian tugas yang jelas yang telah dirumuskan, sedangkan organisasi informal tidak memiliki pembagian tugas yang tegas.

2. Dalam organisasi formal terdapat mata rantai perintah yang tegas, sebaliknya dalam organisasi informal tidak terdapat mata rantai perintah yang tegas.

3. Organisasi formal memiliki rencana kerja yang jelas, organisasi informal tidak memiliki rencana kerja yang jelas.

4. Organisasi formal memiliki departemen-departemen, sedangkan organisasi informal tidak dibagi ke dalam departemen.

5. Organisasi formal memiliki tingkatan-tingkatan manajemen yang jelas, sedangkan dalam organisasi informal tidak memilikinya.

Proses informasi yang cepat karena kemajuan teknologi semakin membuat horizon kehidupan semakin meluas sekaligus semakin mengerut. Hal ini berarti berbagai masalah kehidupan manusia menjadi masalah global atau setidaktidaknya tidak dapat dilepaskan dari pengaruh kejadian yang lain, baik masalah politik, ekonomi, maupun sosial. ${ }^{15}$

Globalisasi dampaknya terasa memasuki berbagai aspek kehidupan. Disadari atau tidak semua pihak dan kalangan perlu menyikapinya dengan baik. Untuk sektor pendidikan dituntut lebih arif dan bijak dalam menghadapi tantangan global. ${ }^{16}$

David C. Mc Clelland, dalam artikelnya berjudul "Dorongan Hati Menuju Modernisasi", menulis hal berikut:

Mengapa ada sejumlah bangsa yang telah "meluncur" (take off) ke dalam pertumbuhan sosial dan ekonomi secara pesat, sementara ada pula yang mandeg atau merosot? Mengapa negaranegara kota di Yunani, terutama di Atena, mulai pertumbuhannya dalam abad ke enam sebelum Masehi sehingga dalam beberapa abad saja kebudayaan mereka telah menyebar dengan kukuhnya ke dalam akar-akar peradaban Barat? Mengapa bangsa Romawi, yang berkali-kali dikalahkan dalam pertempuran laut melawan orangorang Kartago dalam abad ke empat sebelum Masehi tetap tekun mencari uang untuk membangun armada-armada baru sehingga akhirnya mereka menang juga? Pada waktu orang-orang Romawi tersebut sedang berada dalam suatu taraf ekspansi yang tak bisa dihentikan oleh kekalahan yang besar sekalipun.

\footnotetext{
${ }^{15}$ H.A.R. Tilaar, Manajemen Pendidikan Nasional (Bandung: PT Remaja Rosdakarya, 2008), h. 4.

${ }^{16}$ Nanang Fatah, Analisis Kebijakan Pendidikan (Bandung: PT Remaja Rosdakarya, 2012), h. 64.
} 
Bila kita beralih ke zaman modern ini, mengapa sebagian dari Amerika Utara yang untuk pertama kalinya didiami oleh beberapa orang Inggris, berkembang sangat pesat dalam bidang ekonomi, sedangkan bagian lainnya yang pada mulanya didiami oleh orang Spanyol yang menduga bahwa mereka telah memiliki bidang tahan yang lebih kaya, sampai beberapa waktu yang sangat lambat perkembangannya? Mengapa Jepang dapat meluncur secara ekonomis dalam abad kesembilan belas sedangkan Cina tidak? ${ }^{17}$

Berdasarkan tulisan McClelland, kita dapat membuat perbandinganperbandingan yang lain, akan tetapi itu tidak perlu, sebab persoalannya akan sama, yaitu apakah yang menyebabkan dorongan penyebab terjadinya kemajuankemajuan tersebut? Para ahli dengan berbagai penelitiannya, menyimpulkan bahwa faktor tersebut dapat dipisahkan ke dalam dua kelompok besar, yaitu: faktor manusia dan tata kerja.

Tata kerja yang merupakan salah satu penyebab kemajuan dan pertumbuhan di berbagai bidang. Dewasa ini, hampir setiap kegiatan selalu dilaksanakan di dalam dan melalui lembaga-lembaga yang dimanajemeni. Kondisi ini mendorong tumbuhnya organisasi-organisasi di lingkungan masyarakat. Berbagai kegiatan sosial, mulai dari tingkat RT sampai di tingkat pemerintah pusat, hampir semuanya dilaksanakan di dalam dan melalui organisasi. Dengan demikian, bahwa sekarang ini masyarakat sudah menjadi masyarakat organisasi, yang cirinya setiap kegiatan mencapai tujuan dilaksanakan di dalam dan melalui organisasi. ${ }^{18}$

Seiring berjalannya era globalisasi, maka lingkungan di negara berkembang dengan negara maju sangat berbeda, karena lingkungan pada negara berkembang memiliki karakteristik yang khas, lebih sering berubah dan perubahannya seringkali mendadak, dengan demikian, memiliki kecenderungan yang tak menentu. Pemerintah biasanya, masih banyak melakukan intervensi. Pengambilan keputusan ekonomis dan politis tampak tidak transparan. Oleh karena itu tingkat ketidakpastian menjadi lebih besar. Akibatnya, dapat dikatakan bahwa lingkungan di negara sedang berkembang memiliki pengaruh yang jauh

17 Davis C. McClelland, Dorongan Hati Menuju Modernisasi dalam buku Modernisasi: Dinamika Pertumbuhan, (Voice og Forum Lectures), h. 1.

18 Heidjrachman, Tanya Jawab, h. 8. 
lebih besar dalam menentukan kegagalan atau keberhasilan manajemen dibandingkan di negara maju.

Analisis lingkungan adalah suatu proses monitoring terhadap lingkungan organisasi yang bertujuan untuk mengidentifikasikan peluang (opportunities) dan tantangan (threats) yang mempengaruhi kemampuan organisasi untuk mencapai tujuannya. Tujuan dilakukan analisis lingkungan adalah mengantisipasi lingkungan organisasi sehingga dapat bereaksi secara cepat dan tepat untuk mensukseskan organisasi. Analisis lingkungan adalah suatu proses yang digunakan perencana-perencana strategi untuk memantau lingkungan dalam menentukan peluang atau ancaman.

Lingkungan perlu dianalisis karena: ${ }^{19}$

a. Agar pembuat strategi dapat mengantisipasi setiap kesempatan dan membantu mengembangkan sistem pemecahan tujuan perusahaan/organisasi (early warning system).

b. Untuk dapat mengefektifkan proses manajemen strategi, karena dengan melakukan analisis lingkungan hasil yang akan diperoleh lebih efektif.

c. Untuk membantu manajer dalam meramalkan dampak lingkungan terhadap perkembangan perusahaan/lembaga. Terkumpulnya berbagai organisasi dari lingkungan, memudahkan untuk membuat perencanaan jangka panjang.

Analisis Lingkungan dapat dilakukan dengan 3 (tiga) cara, yaitu: ${ }^{20}$

a. Menganalisis hubungan antara strategi perusahaan/lembaga dan tanggapan terhadap lingkungan, yang dipakai sebagai landasan untuk membandingkan strategi yang sedang berjalan dengan strategi yang potensial yang akan datang.

b. Menganalisis kecenderungan faktor dan masalah utama yang potensial yang akan datang.

c. Mencoba meramalkan kemungkinan yang akan terjadi pada masa akan datang terhadap lingkungan.

Pada dasarnya struktur lingkungan dapat dibagi atau dibedakan menjadi dua elemen utama, yaitu: lingkungan eksternal (makro) dan lingkungan internal (mikro).

Pengorganisasian adalah memutuskan cara terbaik untuk mengelompokkan aktivitas dan sumber daya organisasi. Seperti anak-anak memilih berbagai jenis balok permainan yang berbeda untuk membuat mainan kastil, manajer dapat

\footnotetext{
${ }^{19} \mathrm{http}: / /$ adhi-ok.blogspot.com/2011/09/analisa-kekuatan-lingkungan-globalisasi.html.
}

${ }^{20}$ Ibid. 
memilih serangkaian kemungkinan struktural. Dan seperti anak-anak yang dapat menyusun balok dengan sejumlah cara, manajer dapat menyusun organisasi dalam berbagai cara yang berbeda. Memahami sifat dari balok-balok permainan dan cara yang berbeda untuk mengkonfigurasikannya dapat memiliki dampak kuat terhadap daya saing suatu perusahaan/lembaga. ${ }^{21}$

Dinamika organisasi yang harus dikelola secara cerdas dan konstruktif ialah terletak pada konflik yang sering timbul di suatu organisasi, karena dalam kenyataannya konflik tidak selamanya bersifat destruktif akan tetapi akan mampu meningkatkan produktivitas suatu organisasi apabila dapat di atasi dan dikelola dengan baik.

a. Pengertian Konflik

Konflik biasanya timbul dalam organisasi sebagai hasil adanya masalah-masalah komunikasi, hubungan pribadi, atau struktur organisasi. Karakteristik-karakteristik kepribadian tertentu, seperti otoriter atau dogmatis juga dapat menimbulkan konflik. Arti konflik banyak dikacaukan dengan banyaknya definisi dan konsepsi yang saling berbeda. Pada hakekatnya konfilk dapat didefinisikan sebagai segala macam interaksi pertentangan atau antagonistik antara dua atau lebih pihak. Konflik Organisasi (organizational conflict) adalah ketidaksesuaian antara dua atau lebih anggota-anggota atau kelompok organisasi yang timbul karena adanya kenyataan bahwa mereka harus membagi sumber daya- sumber daya yang terbatas atau kegiatan-kegiatan kerja dan atau kenyataan bahwa mereka mempunyai perbedaan status, tujuan, nilai dan persepsi. ${ }^{22}$

b. Jenis-Jenis Konflik

Ada lima jenis konflik dalam kehidupan organisasi: ${ }^{23}$

1. Konflik dalam diri individu Konflik terjadi bila pada waktu yang sama seseorang memiliki dua keinginan yang tidak mungkin dipenuhi sekaligus.

2. Konflik antar individu dalam organisasi yang sama karena pertentangan kepentingan atau keinginan. Hal ini sering terjadi antara dua orang yang berbeda status, jabatan, bidang kerja dan lain-lain.

3. Konflik antar individu dan kelompok sering kali berhubungan dengan cara individu menghadapi tekanan-tekanan untuk

${ }^{21}$ Sunarto, Manajemen 2 (Yogyakarta: Amus: 2007), hlm. 4.

22 Ibid.

${ }^{23} \underline{\mathrm{http}: / / \text { beruangkaki5.blogspot.com/2012/06/dinamika-organisasi.html }}$ 
mencapai konformitas, yang ditekankan kepada mereka oleh kelompok kerja mereka.

4. Konflik antar kelompok dalam organisasi yang sama Konflik ini merupakan tipe konflik yang banyak terjadi di dalam organisasi-organisasi. Konflik antar lini dan staf, pekerja dan pekerja.

5. Konflik antar organisasi konflik ini biasanya disebut dengan persaingan.

Dengan demikian dilihat dari jenisnya, konflik bisa terjadi dalam diri individu, antar individu, kelompok, ataupun antar organisasi.

c. Sebab-Sebab Timbulnya Konflik

Setelah mengapa ada konflik, biasanya ada sumber-sumber yang menjadikan konflik tersebut muncul, secara umum biasanya terjadi karena tersebut dibawah ini: ${ }^{24}$

1. Adanya aspirasi yang tidak ditampung.

2. Saling ketergantungan tugas.

3. Ketergantungan satu arah.

4. Ketidakpuasan, perasaan ketidakadilan.

5. Distorsi komunikasi.

6. Tidak ada pedoman.

7. Aturan yang kurang jelas.

8. Kurang transparannya beberapa hal.

Dengan demikian konflik dalam organisasi (organizational conflict) adalah perbedaan pendapat atau pertentangan antara dua atau lebih individu-individu atau kelompok-kelompok atau unit-unit kerja dalam organisasi yang timbul karena adanya kenyataan bahwa mereka harus membagi sumber daya yang terbatas dalam aktivitas kerja dan kenyataan bahwa mereka memiliki tujuan, nilai, persepsi, dan interest yang berbeda. Untuk mencapai tujuan organisasi, tidak jarang terjadi perbedaan persepsi atau pandangan di antara individu atau di antara kelompok individu dalam menerjemahkan misi organisasi sehingga menimbulkan konflik.

d. Mengendalikan Konflik

Konflik agar tidak mengarah destruktif harus bisa dikendalikan, antara lain dengan cara sebagai berikut: Harus sering mengadakan musyawarah, Adanya komunikasi dua arah yang enak dan luwes, Memberi keadilan pada semua lini,Transparan dalam semua hal, Ada pedoman yang

${ }^{24}$ http://haikal-rifki.blogspot.com/2009/12/dinamika-organisasi.html. 
jelas, Ada aturan yang jelas, Semua aspirasi dianggap penting dan dikomunikasikan.

\section{Kesimpulan}

Organisasi merupakan proses kerja sama dua orang atau lebih untuk mencapai tujuan organisasi secara efektif dan efisien. Sedangkan pengorganisasian adalah proses membagi kerja ke dalam tugas-tugas yang lebih kecil, membebankan tugastugas itu kepada orang yang sesuai dengan kemampuannya, dan mengalokasikan sumber daya, serta mengkoordinasikannya dalam rangka efektivitas pencapaian tujuan organisasi.

Pada struktur organisasi tergambar posisi kerja, pembagian kerja, jenis kerja yang harus dilakukan, hubungan atasan dan bawahan, kelompok, komponen atau bagian, tingkat manajemen dan saluran komunikasi. Struktur organisasi menspeksifikasi pembagian kegiatan kerja dan menunjukkan bagaimana fungsi atau kegiatan kerja dan menunjukkan bagaimana fungsi atau kegiatan yang berbeda-beda itu dihubungkan. Pada era globalisasi, lingkungan di negara berkembang dengan negara maju sangat berbeda, karena lingkungan pada negara berkembang memiliki karakteristik yang khas, lebih sering berubah dan perubahannya seringkali mendadak, dengan demikian, memiliki kecenderungan yang tak menentu. Lingkungan di negara sedang berkembang juga memiliki pengaruh yang jauh lebih besar dalam menentukan kegagalan atau keberhasilan manajemen dibandingkan di negara maju.

Dinamika organisasi yang harus dikelola secara cerdas dan konstruktif ialah terletak pada konflik yang sering timbul di suatu organisasi, karena dalam kenyataannya konflik tidak selamanya bersifat destruktif akan tetapi akan mampu meningkatkan produktivitas suatu organisasi apabila dapat di atasi dan dikelola dengan baik. 


\section{DAFTAR PUSTAKA}

E. Kast dan James E. Rosenzweight. 1979. Organization and Management: A System Approach. New York: McGraw Hill Book Co.

Fatah, Nanang. 2009. Landasan Manajemen Pendidikan. Bandung: PT Remaja Rosdakarya. 2012. Analisis Kebijakan Pendidikan. Bandung: PT Remaja Rosdakarya.

G.R. Jones. 1995. Organizational TheoryText and Cases. New York: Addison Wesley Publishing Company.

Handoko. 2003. Manajemen. Yogyakarta: BPEF-UGM.

McClelland, Davis C. Dorongan Hati Menuju Modernisasi dalam buku Modernisasi: Dinamika Pertumbuhan. Voice og Forum Lectures.

Muhaimin, et.al. 2012. Paradigma Pendidikan Islam (Upaya Mengefektifkan Pendidikan Agama Islam di Sekolah). Bandung: PT Remaja Rosdakarya.

Ranupandojo, Heidjrachman. 1996. Teori dan Konsep Manajemen. Yogyakarta: AMP YKPN. 1990. Tanya Jawab Manajemen. Yogyakarta: AMP YKPN.

Sunarto. 2007. Manajemen 2. Yogyakarta: Amus.

Stoner. 1986. Management, alih bahasa Wihelmus W. Bakowatun. Jakarta: Intermedia.

Tilaar, H.A.R. 2008. Manajemen Pendidikan Nasional. Bandung: PT Remaja Rosdakarya.

Usman, Husaini. 2009. Manajemen (Teori, Praktik, dan Riset Pendidikan). Jakarta: Bumi Aksara.

http://www.majalahpendidikan.com/2011/10/fungsi-pengorganisasian-dalammanajemen.html.

http://belajarmanagement.wordpress.com/2010/02/24/bentuk-bentuk-organisasi/. 
http://ulfahfauziyah.blogspot.com/2012/10/bentuk-bentuk-organisasi.html.

http://dedetzelth.blogspot.com/2013/03/bentuk-bentuk-organisasi_17.html.

http://adhi-ok.blogspot.com/2011/09/analisa-kekuatan-lingkunganglobalisasi.html.

http://beruangkaki5.blogspot.com/2012/06/dinamika-organisasi.html

http://haikal-rifki.blogspot.com/2009/12/dinamika-organisasi.html. 